\title{
Synthesis and Anti-Actinomycotic Activity of the Oligomycin A Thiocyanato Derivative Modified at 2-Oxypropyl Side Chain
}

Lyudmila N. Lysenkova, ${ }^{\mathrm{a} @ 1}$ Ivan A. Godovikov, ${ }^{\mathrm{b}}$ Alexander M. Korolev, ${ }^{\mathrm{a}}$ Valery N. Danilenko, ${ }^{\mathrm{c}}$ Olga B. Bekker, ${ }^{\mathrm{c}}$ Dilara A. Mavletova, ${ }^{\mathrm{c}}$ Aleksey A. Vatlin, ${ }^{\mathrm{c}}$ Andrey E. Shchekotikhin, ${ }^{\mathrm{a}, \mathrm{d} @ 2}$ and Maria N. Preobrazhenskaya ${ }^{\mathrm{a}}$

We dedicate this work to the memory of Professor Maria N. Preobrazhenskaya, the eminent scholar in heterocyclic and medicinal chemistry

${ }^{\mathrm{a}}$ G.F. Gause Institute of New Antibiotics, 119021 Moscow, Russian Federation

${ }^{\mathrm{b}}$ A.N. Nesmeyanov Institute of Organoelement Compounds, Russian Academy of Sciences, 119991 Moscow, Russian Federation

${ }^{\mathrm{c}}$ N.I. Vavilov Institute of General Genetics, Russian Academy of Sciences, 119991 Moscow, Russian Federation

${ }^{\mathrm{d} D . I . ~ M e n d e l e e v ~ U n i v e r s i t y ~ o f ~ C h e m i c a l ~ T e c h n o l o g y ~ o f ~ R u s s i a, ~} 125047$ Moscow, Russian Federation

@1 Corresponding authorE-mail:lyudmil-lys@yandex.ru

${ }^{@ 2}$ Corresponding author E-mail: shchekotikhin@mail.ru

\begin{abstract}
A novel way of chemical modification of the antibiotic oligomycin A at the 2-oxypropyl side chain was developed. Previously obtained 33-O-mesyl oligomycin A was used at the reaction with the potassium thiocyanate to produce (33S)33-deoxy-33-thiocyanatooligomycin in $66 \%$ yield. (33S)-33-Deoxy-33-thiocyanatooligomycin A has demonstrated a lower potency active against $S$. fradiae and $S$. albus than oligomycin A.
\end{abstract}

Keywords: (33S)-33-Deoxy-33-thiocyanatooligomycin, oligomycin A, macrolide antibiotic, anti-actinomycotic activity, ATP-synthase inhibitor.

\section{Синтез и противоактиномикозная активность производного олигомицина A, модифицированного тиоцианатом по 2-гидроксипропильной цепи}

\author{
ᄉ. Н. Аысенкова, ${ }_{1}^{\mathrm{a} 1}$ И. А. Годовиков, ${ }^{\text {b }}$ А. М. Королев, ${ }_{1}^{\text {a }}$ В. Н. Ааниленко, ${ }^{c}$ \\ О. Б. Беккер, ${ }^{c}$ A. А. Мавлетова, ${ }^{c}$ А. А. Ватлин, ${ }^{c}$ А. Е. Щекотихин, ${ }^{a, d @ 2}$ \\ М. Н. Преображенская ${ }^{a}$
}
Работа посвящается памяти выgающегося ученого в области гетероциклической и медицинской химии, профессора Марии Преображенской

\footnotetext{
а Институт по изысканию новых антибиотиков им. Г.Ф. Гаузе, 119021 Москва, Россия

${ }^{\mathrm{b}}$ Институт элементоорганических соединений им. А.Н. Несмеянова РАН, 119991 Москва, Россия

'Институт общей генетики им. Н.И. Вавилова РАН, 119991 Москва, Россия

d Российский химико-технологический университет им. Д.И. Менделеева, 125047 Москва, Россия

@1E-mail: lyudmil-lys@yandex.ru

@2E-mail: shchekotikhin@mail.ru
} 
Разработан новый способ химической модификаџии антибиотика олигомиичина А в боковой иепи. Взаимодействием 33-О-мезилолигомицина с тиоцианатом калия синтезирован (33S)-33-дезокси-33тиоцианатоолигомицин с выходом 66 \%. (33S)-33-Дезокси-33-тиоцианатоолигомицин показал несколько меньшую активность в отношении $S$. fradiae u $S$. albus, чем исходный олигомицин A.

Ключевые слова: (33S)-33-Дезокси-33-тиоцианатоолигомицин, олигомицин А, макролидный антибиотик, противоактиномикозная активность, АТФ-синтаза.

\section{Introduction}

Oligomycin A, an inhibitor of $\mathrm{F}_{0} \mathrm{~F}_{1}$ ATP synthases of bacteria and eukaryotes, disrupts bioenergetic metabolism. ${ }^{[1,2]}$ The extremely high potency of oligomycin A makes this antibiotic an attractive scaffold for rational design of new chemotherapeutic agents. Oligomycins belong to the class of macrolide antibiotics which have highly functionalized molecules with keto- and hydroxyl groups, lactone and spiro moieties, and double bonds. The complexity of oligomycin and its lability in basic conditions ${ }^{[3]}$ significantly impede drug modification and applicability. These challenges have prompted us to develop preparative ways to diversify the oligomycin scaffold. Additionally, novel semi-synthetic derivatives with a point modification of functional groups at oligomycin A (1) would be also valuable for SAR studies, validation of intracellular targets, and depicting the mechanism of $\mathrm{F}_{0} \mathrm{~F}_{1}$ ATP synthase inhibition. ${ }^{[4]}$ Of interest is the development of modifications of the oligomycin A 2-oxypropyl side chain, as a hydroxyl group of this moiety plays a key role at the inhibition of proton translocation in $\mathrm{F}_{0} \mathrm{~F}_{1}$ ATP synthase. ${ }^{[5]}$ Recently a fluorinated oligomycin A has been obtained selectively despite the presence of five hydroxyl groups indicating the special properties of $33-\mathrm{OH}$ group. ${ }^{[6]}$

\section{Experimental}

(33S)-33-Deoxy-33-thiocyanatooligomycin $\mathrm{C}_{46} \mathrm{H}_{73} \mathrm{NO}_{10} \mathrm{~S}$ (3). To a stirring solution of 33-O-mesyl-oligomycin $A(2)^{[7]}(30 \mathrm{mg}$, $0.034 \mathrm{mmol})$ in hexamethylphosphoric triamide (HMPA) $(3.5 \mathrm{ml})$ under argon flow, KSCN (67 mg, $0.7 \mathrm{mmol})$ was added. A flask with reaction mixture was put into the bath heated to $105{ }^{\circ} \mathrm{C}$. The temperature was kept at $105-115{ }^{\circ} \mathrm{C}$. An additional portion of $\operatorname{KSCN}(0.015 \mathrm{~g}, 0.15 \mathrm{mmol})$ was added after $1 \mathrm{~h}$. The reaction mixture was stirred for $3 \mathrm{hrs}$; after the reaction was completed (TLC analyzed in hexane/acetone, 10:7), the resulting solution was cooled and quenched by adding water $(10 \mathrm{ml})$. The aqueous

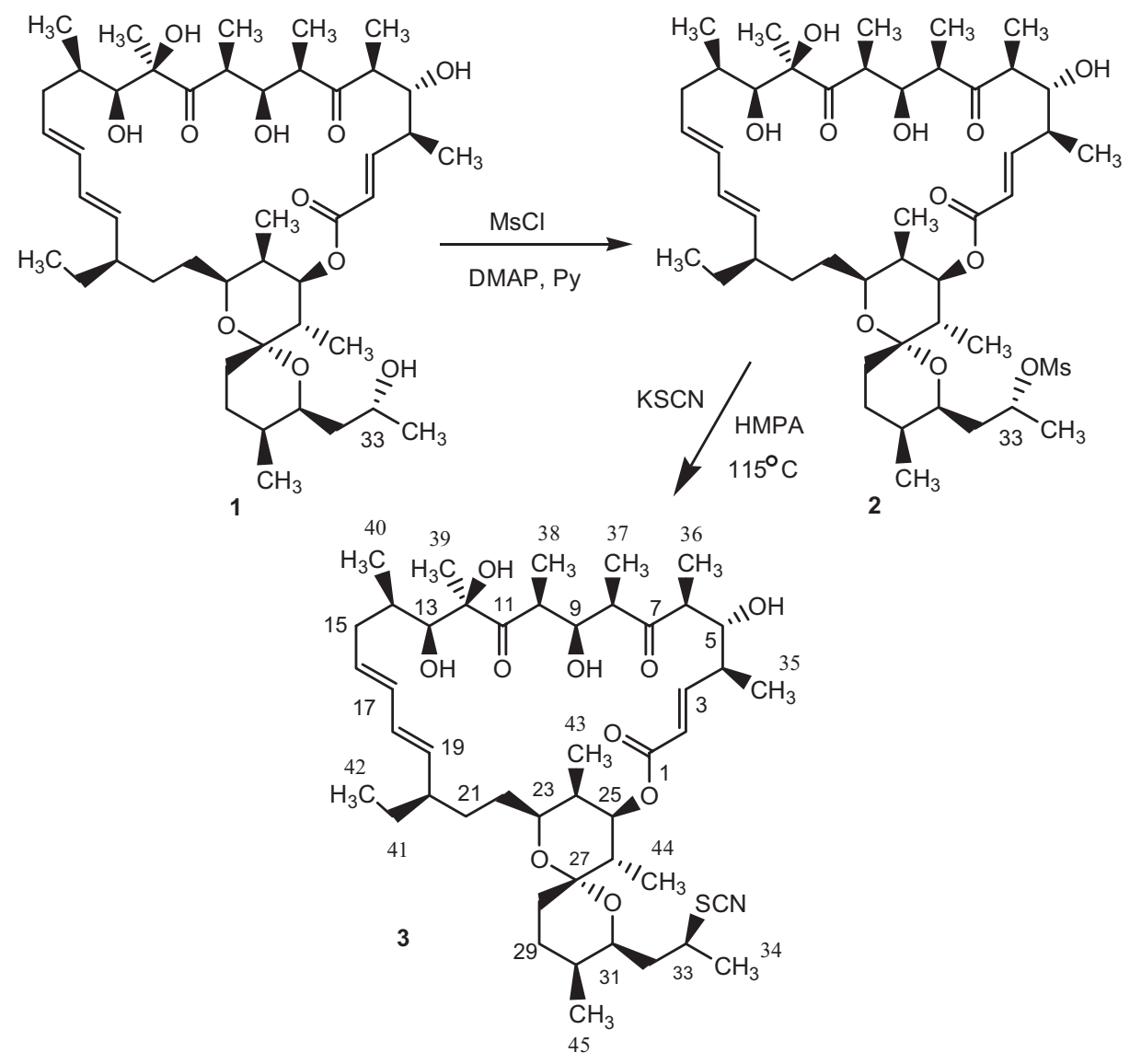

Figure 1. Synthesis of (33S)-33-deoxy-33-thiocyanatooligomycin A 3. 
Synthesis and Anti-Actinomycotic Activity of the Oligomycin A Thiocyanato Derivative

Table 1. ${ }^{1} \mathrm{H}$ and ${ }^{13} \mathrm{C}$ NMR spectra of compounds $\mathbf{2}$ and $\mathbf{3}$ with comparison to oligomycin $\mathrm{A} \mathbf{1}$ in $\mathrm{CDCl}_{3}$.

\begin{tabular}{|c|c|c|c|c|c|c|c|}
\hline \multirow{2}{*}{$\begin{array}{l}\text { Posi- } \\
\text { tion }\end{array}$} & \multirow[t]{2}{*}{ Type } & \multicolumn{2}{|r|}{ Oligomycin A (1) } & \multicolumn{2}{|c|}{ 33-O-Mesyloligomycin A (2) } & \multicolumn{2}{|c|}{$\begin{array}{c}\text { 33-Deoxy-33-thiocyanato-oligomycin } \\
\text { A (3) }\end{array}$} \\
\hline & & $\delta_{\mathrm{C}}, \mathrm{ppm}$ & $\delta_{\mathrm{H}}, \mathrm{ppm}$, mult $(J$ in $\mathrm{Hz})$ & $\delta_{\mathrm{C}}, \mathrm{ppm}$ & $\delta_{\mathrm{H}}, \mathrm{ppm}$, mult $(J$ in $\mathrm{Hz})$ & $\delta_{\mathrm{C}}, \mathrm{ppm}$ & $\delta_{\mathrm{H}}, \mathrm{ppm}$, mult $(J$ in $\mathrm{Hz})$ \\
\hline 1 & $\mathrm{O}=\mathrm{CO}$ & 165.0 & - & 165.0 & - & 165.1 & - \\
\hline 2 & $\mathrm{CH}$ & 122.6 & 5.80, dd $(15.6,0.7)$ & 122.6 & 5.80, dd $(15.7,0.7)$ & 122.7 & $5.86, \mathrm{~d}(15.3)$ \\
\hline 3 & $\mathrm{CH}$ & 148.3 & $6.62, \mathrm{dd}(15.6,10.1)$ & 148.4 & $6.62, \mathrm{dd}(15.6,10.0)$ & 148.6 & $6.67, \mathrm{dd}(15.3,10.8)$ \\
\hline 4 & $\mathrm{CH}$ & 40.1 & $2.36, \operatorname{tq}(10.0,6.6)$ & 40.0 & $2.37, \operatorname{tq}(10.0,6.5)$ & 40.2 & $2.42, \mathrm{~m}$ \\
\hline 5 & $\mathrm{CH}$ & 72.9 & 3.75 , dd $(10.1,1.3)$ & 72.9 & 3.76, dd $(10.1,1.2)$ & 73.0 & $3.82, \mathrm{~d}(9.8)$ \\
\hline 6 & $\mathrm{CH}$ & 46.4 & $2.70, \mathrm{dq}(1.3,7.4)$ & 46.5 & $2.71, \mathrm{qd}(7.3,1.3)$ & 46.7 & $2.74, \mathrm{~m}$ \\
\hline 7 & $\mathrm{C}=\mathrm{O}$ & $220.2^{\mathrm{a})}$ & - & $220.2^{\text {a) }}$ & - & 220.4 & - \\
\hline 8 & $\mathrm{CH}$ & $41.9^{\mathrm{b})}$ & $3.59, \mathrm{dq}(8.6,6.9)$ & $41.8^{\mathrm{b})}$ & $3.58, \mathrm{dq}(8.4,6.9)$ & 41.7 & $3.35, \mathrm{~m}$ \\
\hline 9 & $\mathrm{CH}$ & 72.6 & $3.94, \mathrm{dd}(8.6,3.1)$ & 72.5 & $3.94, \mathrm{dd}(8.4,3.0)$ & 72.3 & $3.98, \mathrm{~m}$ \\
\hline 10 & $\mathrm{CH}$ & $45.6^{\mathrm{b})}$ & $2.74, \mathrm{dq}(3.0,7.1)$ & $45.6^{\mathrm{b})}$ & 2.75, qd $(7.0,3.0)$ & 45.7 & $2.8 \mathrm{~m}$ \\
\hline 11 & $\mathrm{C}=\mathrm{O}$ & $219.9^{\text {a) }}$ & - & $219.8^{\mathrm{a})}$ & - & 220.0 & - \\
\hline 12 & $\mathrm{C}-\mathrm{O}$ & 82.9 & - & 82.9 & - & 83.1 & - \\
\hline 13 & $\mathrm{CH}$ & 72.2 & $3.89, \mathrm{~d}(1.9)$ & 72.2 & $3.92, \mathrm{~d}(1.8)$ & 68.5 & $3.84, \mathrm{~m}$ \\
\hline 14 & $\mathrm{CH}$ & 33.4 & $1.88, \mathrm{~m}$ & 33.4 & $1.85, \mathrm{~m}$ & 45.9 & $1.92, \mathrm{~m}$ \\
\hline 15 & $\mathrm{CH}_{2}$ & 38.3 & $2.17, \mathrm{bd} ; 1.98 \mathrm{dt}$ & 38.4 & $2.18, \mathrm{~m} ; 1.97, \mathrm{~m}$ & 38.38 & $1.28, \mathrm{~m} ; 1.46, \mathrm{~m}$ \\
\hline 16 & $\mathrm{CH}$ & 129.3 & 5.42, ddd $(14.8,10.5,4.1)$ & 129.3 & $\begin{array}{c}5.44, \text { ddd } \\
(14.7,10.6,3.9)\end{array}$ & 129.8 & $5.49, \mathrm{t}(11.0)$ \\
\hline 17 & $\mathrm{CH}$ & 132.3 & $6.00, \operatorname{ddd}(14.7,10.4,1.4)$ & 132.3 & $\begin{array}{c}6.01, \text { ddd } \\
(14.6,10.3,1.6)\end{array}$ & 130.6 & $5.98, \mathrm{~m}$ \\
\hline 18 & $\mathrm{CH}$ & 130.2 & $5.90, \mathrm{dd}(14.9,10.5)$ & 130.3 & $5.92, \mathrm{dd}(14.7,10.4)$ & 132.4 & $6.05, \mathrm{~m}$ \\
\hline 19 & $\mathrm{CH}$ & 137.7 & 5.21, dd $(14.8,9.6)$ & 137.6 & $5.24, \mathrm{dd}(14.7,9.6)$ & 137.3 & $5.27, \mathrm{dd}(15.3,9.9)$ \\
\hline 20 & $\mathrm{CH}$ & 45.9 & $1.85, \mathrm{~m}$ & 45.7 & $1.85, \mathrm{~m}$ & 45.74 & $1.92, \mathrm{~m}$ \\
\hline 21 & $\mathrm{CH}_{2}$ & 31.4 & $1.52, \mathrm{~m} ; 1.35, \mathrm{~m}$ & 31.4 & $1.40, \mathrm{~m}$ & 38.5 & $1.94, \mathrm{~m} ; 2.17 \mathrm{~m}$ \\
\hline 22 & $\mathrm{CH}_{2}^{2}$ & 30.9 & 1.59, ddd & 30.4 & $1.59, \mathrm{~m} ; 1.07, \mathrm{~m}$ & 30.7 & $1.18-1.23, \mathrm{~m}$ \\
\hline 23 & $\mathrm{CH}$ & 68.9 & 3.78, ddd $(9.8,2.7,2.4)$ & 69.1 & $\begin{array}{c}3.71, \text { ddd } \\
(10.0,3.7,2.1)\end{array}$ & 41.97 & $3.63, \mathrm{~m}$ \\
\hline 24 & $\mathrm{CH}$ & 35.7 & 2.11, ddq $(5.0,2.2,6.9)$ & 35.6 & $\begin{array}{c}2.11, \mathrm{ddq} \\
(5.0,2.0,7.0)\end{array}$ & 35.8 & $2.16, \mathrm{~m}$ \\
\hline 25 & $\mathrm{CH}$ & 76.1 & $4.91, \mathrm{dd}(11.4,5.0)$ & 75.8 & 4.93, dd $(11.4,4.9)$ & 75.9 & 4.99, dd $(12.0,4.3)$ \\
\hline 26 & $\mathrm{CH}$ & 37.6 & $1.78, \mathrm{dq}(11.4,6.6)$ & 37.6 & $1.78, \mathrm{dq}(11.4,6.6)$ & 37.7 & $1.83, \mathrm{~m}$ \\
\hline 27 & $\mathrm{OCO}$ & 99.1 & - & 99.2 & - & 99.5 & - \\
\hline 28 & $\mathrm{CH}_{2}$ & 25.9 & $1.90, \mathrm{~m} ; 1.23, \mathrm{~m}$ & 25.8 & $1.88, \mathrm{~m} ; 1.22, \mathrm{~m}$ & 21.8 & $1.46, \mathrm{~m} ; 1.28 \mathrm{~m}$ \\
\hline 29 & $\mathrm{CH}_{2}$ & 26.4 & $2.07, \mathrm{~m} ; 1.38, \mathrm{~m}$ & 26.1 & $2.08, \mathrm{~m} ; 1.48, \mathrm{~m}$ & 26.23 & $1.96, \mathrm{~m} ; 2.21, \mathrm{~m}$ \\
\hline 30 & $\mathrm{CH}$ & 30.4 & $1.54, \mathrm{~m}$ & 29.6 & $1.60, \mathrm{~m}$ & 33.6 & $1.99, \mathrm{~m}$ \\
\hline 31 & $\mathrm{CH}$ & 67.1 & $3.96, \mathrm{dt}(10.3,2.5)$ & 67.9 & $\begin{array}{c}3.83, \text { ddd } \\
(8.2,5.0,2.5)\end{array}$ & 69.6 & $3.70, \mathrm{~m}$ \\
\hline 32 & $\mathrm{CH}_{2}$ & 42.4 & $1.55, \mathrm{~m} ; 1.25 \mathrm{~m}$ & 40.6 & $1.83, \mathrm{~m} ; 1.73, \mathrm{~m}$ & 40.9 & $1.80, \mathrm{~m} ; 1.98, \mathrm{~m}$ \\
\hline 33 & $\mathrm{CH}$ & 64.6 & $\begin{array}{c}4.00, \mathrm{ddq} \\
(9.2,3.1,6.2)\end{array}$ & 78.2 & $4.87, \mathrm{ddq}$ & 41.8 & $3.35, \mathrm{~m}$ \\
\hline 34 & $\mathrm{CH}_{3}$ & 24.6 & $1.21, \mathrm{~d}(6.2)$ & 22.0 & $1.48, \mathrm{~d}(6.2)$ & 22.5 & $1.62, \mathrm{~d}(6.6)$ \\
\hline 35 & $\mathrm{CH}_{3}$ & 17.8 & $1.16, \mathrm{~d}(6.6)$ & 17.8 & $1.16, \mathrm{~d}(6.5)$ & 18.0 & $1.22, \mathrm{~d}(6.0)$ \\
\hline 36 & $\mathrm{CH}_{3}$ & 8.2 & $1.05, \mathrm{~d}(7.3)$ & 8.2 & $1.05, \mathrm{~d}(7.3)$ & 8.4 & $1.10, \mathrm{~d}(7.3)$ \\
\hline 37 & $\mathrm{CH}_{3}$ & 14.0 & $1.09, \mathrm{~d}(6.9)$ & 13.9 & $1.08, \mathrm{~d}(6.9)$ & 14.2 & $1.13, \mathrm{~d}(6.1)$ \\
\hline 38 & $\mathrm{CH}_{3}$ & 9.2 & $1.01, \mathrm{~d}(7.0)$ & 9.3 & $1.02, \mathrm{~d}(7.0)$ & 9.4 & $1.06, \mathrm{~d}(6.6)$ \\
\hline 39 & $\mathrm{CH}_{3}$ & 20.9 & $1.11, \mathrm{~s}$ & 20.9 & $1.12, \mathrm{~s}$ & 21.0 & $1.16, \mathrm{~s}$ \\
\hline 40 & $\mathrm{CH}_{3}$ & 14.4 & $0.98, \mathrm{~d}(6.6)$ & 14.4 & $0.98, \mathrm{~d}(6.6)$ & 11.1 & $0.94, \mathrm{~d}(6.9)$ \\
\hline 41 & $\mathrm{CH}_{2}$ & 28.4 & $1.35, \mathrm{~m} ; 1.25, \mathrm{~m}$ & 28.2 & $1.35, \mathrm{~m} ; 1.25, \mathrm{~m}$ & 28.5 & $1.39, \mathrm{~m} ; 1.29, \mathrm{~m}$ \\
\hline 42 & $\mathrm{CH}_{3}$ & 12.0 & $0.80, \mathrm{t}(7.4)$ & 12.0 & $0.81, \mathrm{t}(7.4)$ & 12.1 & $0.86, \mathrm{~m}$ \\
\hline 43 & $\mathrm{CH}_{3}$ & 6.0 & $0.82, \mathrm{~d}(6.9)$ & 5.9 & $0.82, \mathrm{~d}(6.9)$ & 6.0 & $0.87, \mathrm{~d}(6.0)$ \\
\hline 44 & $\mathrm{CH}_{3}$ & 11.7 & $0.95, \mathrm{~d}(6.6)$ & 11.7 & $0.94, \mathrm{~d}(6.6)$ & 12.1 & $1.00, \mathrm{~d}(6.0)$ \\
\hline 45 & $\mathrm{CH}_{3}$ & 11.1 & $0.88, \mathrm{~d}(6.9)$ & 11.0 & $0.91, \mathrm{~d}(7.0)$ & 14.5 & $1.03, \mathrm{~d}(6.4)$ \\
\hline 46 & S-C & - & - & 39.1 & $2.99 \mathrm{~s}$ & 111.3 & - \\
\hline
\end{tabular}

a), b) Assignment of reverse signals of the same compound, labeled the same letters. 
solution was extracted with EtOAc $(2 \times 20 \mathrm{ml})$. The combined organic layer was carefully washed with water $(5 \times 20 \mathrm{ml})$, brine $(20$ $\mathrm{ml}$ ), dried over $\mathrm{Na}_{2} \mathrm{SO}_{4}$ and evaporated. The residue was purified twice by column chromatography on silica gel in hexane:acetone (10:7) and then $\mathrm{CHCl}_{3}: \mathrm{MeOH}(10: 0.5)$ After evaporation of the solvent a colorless amorphous powder was obtained. Yield: $0.019 \mathrm{~g}$ $(66 \%) . \mathrm{R}_{\mathrm{f}}=0.58$ (hexane:acetone, 10:7); $\mathrm{R}_{\mathrm{t}}=17.11,96.4 \%$. Mass spectrum (ESI) $m / z(\%): 854.4861(100)\left[(\mathrm{M}+\mathrm{Na})^{+}\right]$. IR (film) $v$ $\mathrm{cm}^{-1}: 3447$ m, 2969 s, 2933 s, 2875 s, 2152 w, 1713 s, 1651 w, 1457 s, $1384 \mathrm{~m}, 1333 \mathrm{~m}, 1273 \mathrm{~m}, 1223 \mathrm{~m}, 1173 \mathrm{~s}, 1090 \mathrm{~m}, 984 \mathrm{~s}, 894$ $\mathrm{s}$ (Figure S11). UV-Vis $\left(\mathrm{CH}_{3} \mathrm{OH}\right) \lambda \mathrm{nm}(\lg \varepsilon): 260$ (4.4), 280 (4.2) (Figure S10). $[\alpha]_{\mathrm{D}}{ }^{20}-41.6^{\circ}$ (c 0.576 , methanol). M.p.: $103-104{ }^{\circ} \mathrm{C}$.

Evaluation of the antibacterial activity of compounds 1 and 3. The antibacterial activity of oligomycin A (1) and its derivative (3) was determined as the diameter of the growth inhibition halo of $S$. fradiae ATCC-19609 cells around paper discs impregnated with tested compounds. ${ }^{[8]}$ The agar MG medium ( $0.7 \%$ agar), $\mathrm{pH}$ $=7.5$, was mixed with $S$. fradiae spore suspension $\left(10^{7}\right.$ spores per dish) and plated on Petri dishes with agar MG medium (2\% agar). Dishes were overlaid with paper discs containing different concentrations of tested compounds. The growth inhibition halo was measured after incubation for $24 \mathrm{hrs}$ at $28{ }^{\circ} \mathrm{C}$. The compound's concentrations showed the smallest halo diameter were compared.

The details of measurements are given in Supplementary Information.

\section{Results and Discussion}

Previously the selective transformation of 33-hydroxyl group of oligomycin A side chain $\mathbf{1}$ into 33-mesyloxy group was observed. ${ }^{[7]}$ The reaction of 1 with methanesulfonyl chloride in pyridine in the presence of DMAP has resulted to 33-O-mesylate of oligomycin $\mathbf{2}$ with a good yield. It is known that the mesyloxy moiety is an excellent leaving group that can be replaced with wide range of nucleophiles. Therefore, further studies toward the transformation of $\mathbf{2}$ were pursued. In this study, we have described the modification of $\mathbf{2}$ into (33S)-33-deoxy-33-thiocyanatooligomycin A $\mathbf{3}$ and compared their antibiotic activity.

After extensive studies, we have found the reaction conditions for successful transformation of $\mathbf{2}$ to $\mathbf{3}$ (Figure 1). Treatment of $\mathbf{2}$ with an excess of KSCN in hexamethylphosphoric triamide (HMPA) at $105-115{ }^{\circ} \mathrm{C}$ for 3-4 hrs has given 3 in good yield (66\%). To avoid side reactions, a flask with reaction mixture was put into the bath heated to $105^{\circ} \mathrm{C}$. We were unable to accomplish this reaction in other solvents such as $N, N$-dimethylformamide, $\mathrm{N}, \mathrm{N}$-dimethylacetamide, or $\mathrm{N}$-methylpyrrolidone.

The structure of $\mathbf{3}$ was confirmed by ${ }^{1} \mathrm{H}$ and ${ }^{13} \mathrm{C}$ NMR studies, high-resolution mass spectrometry (HRMS ESI), and IR spectroscopy. The assigned stereochemistry of $\mathbf{3}$ was based on the general features of $\mathrm{S}_{\mathrm{N}}$-type reactions, which led to Walden inversion of substituents at 33-C. The strong characteristic band at $2153 \mathrm{~cm}^{-1}$ for the $\mathrm{SCN}$ group was observed in the IR spectrum of $\mathbf{3}$.

In ${ }^{1} \mathrm{H}$ and ${ }^{13} \mathrm{C}$ NMR spectra of $\mathbf{3}$ the sizeable low field shifts of $33-\mathrm{H}$ signal $\left(\Delta \delta_{\mathrm{H}} \sim 3.5 \mathrm{ppm}\right)$ and $33-\mathrm{C}\left(\Delta \delta_{\mathrm{C}} \sim 37 \mathrm{ppm}\right)$ were noted in comparison with corresponding signals of $\mathbf{2}$. Additionally, the quaternary signal at $111.26 \mathrm{ppm}$ in ${ }^{13} \mathrm{C}$ NMR spectra and JMOD-HQ experiment have proved the structure of (33S)-33-deoxy-33-thiocyanatooligomycin A (3). The NMR spectra (Table 1) were elucidated using 2D ${ }^{1} \mathrm{H}^{1} \mathrm{H}$-COSY, ${ }^{1} \mathrm{H}^{1} \mathrm{H}$-NOESY and 2D inverse hetero ${ }^{1} \mathrm{H}^{13} \mathrm{C}$ $\mathrm{HMQC}$ and ${ }^{1} \mathrm{H}^{13} \mathrm{C}-\mathrm{HMBC}$ correlations (Figures S1-S9).

Actinobacteria of the Streptomyces genus, a cause of actinomycosis, has been found to be more sensitive to 1 than other bacteria. ${ }^{[9]}$ The Streptomyces fradiae strain highly sensitive to 1 (MIC $<0.001 \mathrm{nmol} / \mathrm{ml},<0.0005 \mathrm{nmol} / \mathrm{disc}$ ) has been validated by us as a useful test system for screening the derivatives of $1{ }^{[8]}$ To estimate the activity of the novel semi-synthetic derivative 3, we have tested its potency against $S$. fradiae in comparison with 1 . The screening has shown that although $\mathbf{3}$ has strongly inhibited the growth of the test culture at subnanomolar concentrations (Table 2), it was noticeably less potent than $\mathbf{1}$. This result has correlated with crystallographic data for a drug-enzyme complex that showed an important role of the hydroxyl group in the propanol side chain of oligomycin A $\mathbf{1}$ for binding to subunit $c$ of the $\mathrm{F}_{0} \mathrm{~F}_{1}$ ATP synthase. ${ }^{[4]}$

\section{Conclusions}

We have developed a method for a point modification of the complex molecule of oligomycin A at the position 33 of the side chain. Although (33S)-33-deoxy-33thiocyanatooligomycin A 3 obtained by this method was less potent against $S$. fradiae and $S$. albus than oligomycin A, $\mathbf{3}$ can be useful for investigation of the action mechanism of oligomycins and functioning of ATP synthase in eukaryotic or microbial cells. Further development of the routes to transform 33-O-mesyl-oligomycin A (2) potentially useful for diversification of oligomycin $\mathrm{A}$ is in progress.

Acknowledgements. This study was supported by grants of the Russian Science Foundation (agreement № 15-1500141). The authors thank A. N. Maliutina (Gause Institute of New Antibiotics) for IR, UV and HPLS analysis.

Table 2. Comparative in vitro activity of oligomycin A and (33S)-33-thiocyanate derivative against S. fradiae ATCC-19609 and S. albus ATCC-21132.

\begin{tabular}{cccccc}
\hline & \multicolumn{2}{c}{ Compound } & \multicolumn{2}{c}{ Oligomycin A (1) } & \multicolumn{2}{c}{ 33-Deoxy-33-thiocyanatooligomycin (3) } \\
\hline \multicolumn{2}{c}{ Concentration, nmol/disc ${ }^{\text {a) }}$} & 0.001 & 0.01 & 0.01 & 0.1 \\
\hline \multirow{2}{*}{ Halo } & S. fradiae ATCC-19609 & $10.0 \pm 0.3^{\text {b) }}$ & $19.0 \pm 0.5$ & $9.0 \pm 0.5$ & $12.0 \pm 0.5$ \\
diameter, $\mathrm{mm}$ & S. albus ATCC-21132 & - & $10.5 \pm 0.5$ & - & $7.5 \pm 0.5$ \\
\hline
\end{tabular}

a) disc diameter $7 \mathrm{~mm}$;

b) \pm S.D. of three independent measurements. 
Synthesis and Anti-Actinomycotic Activity of the Oligomycin A Thiocyanato Derivative

\section{References}

1. Antoniel M., Giorgio V., Fogolari F., Glick G.D., Bernardi P., Lippe G. Int. J. Mol. Sci. 2014, 15(5), 7513-7536.

2. Pagliarani A., Nesci S., Ventrella V. Mitochondrion 2013, 13, 312-319.

3. Lysenkova L.N., Turchin K.F., Korolev A.M., Danilenko V.N., Bekker O.B., Dezhenkova L.G., Shtil A.A., Preobrazhenskaya M.N. J. Antibiot. 2014, 67, 153-158.

4. Symersky J., Osowski D., Walters D.E., Mueller D.M. Proc. Natl. Acad. Sci. USA 2012, 109, 13961-13965.
5. Salomon A.R., Voehringer D.W., Herzenberg L.A., Khosla C. Proc. Natl. Acad. Sci. USA 2000, 97, 14766-14771.

6. Sladojevich F., Arlow S., Tang P., Ritter T. J. Am. Chem. Soc. 2013, 135, 2470-2473.

7. Lysenkova L.N., Turchin K.F., KorolevA.M., Dezhenkova L.G., Bekker O.B., Shtil A.A., Danilenko V.N., Preobrazhenskaya M.N. Bioorg. Med. Chem. 2013, 21, 2918-2924.

8. Alekseeva M.G., Elizarov S.M., Bekker O.B., Lubimova I.K., Danilenko V.N. Biochem. (Moscow) Suppl. A Membr. Cell. Biol. 2009, 3, 16-23.

9. Hensel M., Achmus H., Deckers-Hebestreit G., Altendorf K. Biochem. Biophys. Acta 1996, 1274, 101-108.

Received 16.10.2015 Accepted 14.11.2015 